\title{
Origin of carbon dioxide occurrences in Central Anatolia (Turkey)
}

\author{
HAKAN HOŞGÖRMEZ* and DOĞACAN ÖZCAN \\ Geology Department, Engineering Faculty, Istanbul University, TR-34850, Avcilar, Istanbul, Turkey
}

(Received March 13, 2014; Accepted August 18, 2014)

\begin{abstract}
The occurrence of carbon dioxide $\left(\mathrm{CO}_{2}\right)$ in Central Anatolia has been well-known for 50 years. Four gas producing fields (Bozkar, Guneygaz, Karbogaz, and Terra) are located in the region. The aim of this study was to define the composition of these gas occurrences and to determine the gas origin. For this purpose, the molecular and isotopic composition of gas samples from production wells were investigated and interpreted. Gases from the region are rich in $\mathrm{CO}_{2}(>80 \%)$. Carbon dioxide concentrations were found to vary from 80.7 to $94.3 \%$. The total amount of methane components $\left(\mathrm{CH}_{4+}\right)$ was less than $0.1 \%$. The isotopic composition of $\mathrm{CO}_{2}$, with values between -1.76 and $1.02 \%$, indicated abiogenic origin from limestone. The generation of $\mathrm{CO}_{2}$ could largely result from the decarbonation of limestone. Helium isotopic values indicated that a minor amount of $\mathrm{CO}_{2}$ originated from the mantle. $\delta^{13} \mathrm{C}$ values for methane from the Karbogaz Field suggested that the origin of the Aksaray Field methane is thermogenic.
\end{abstract}

Keywords: origin of gases, hydrocarbon gases, carbon dioxide, generation mechanism of $\mathrm{CO}_{2}$, Central Anatolia, Turkey

\section{INTRODUCTION}

Central Anatolia is the most productive region in Turkey for carbon dioxide. Since 1980, several wells have been drilled for carbon dioxide production. The depth of carbon dioxide production wells varies between 50 and $450 \mathrm{~m}$. Four $\mathrm{CO}_{2}$ gas fields (Bozkar, Guneygaz, Karbogaz, and Terragaz) are currently in production (Fig. 1a).

In Central Anatolia, Upper Cretaceous-Eocene basement blocks belonging to the Eurasian and Afro-Arabian plates are covered by rocks of pyroclastic and volcanic deposits (Pearce et al., 1990; Toprak and Göncüoğlu, 1993; Yılmaz et al., 1998; Kuşçu et al., 2007; Gevrek and Kazanc1, 2000; Piper et al., 2002). These units can briefly be summarized as follows: a) basement rocks (Cretaceous) composed of metamorphic and Cenozoic volcanic rocks; b) Lower Eocene limestone, gypsum, and anhydrite, followed by Cenozoic volcanism (Fig. 1a). Cenozoic volcanic activity is concentrated within a triangular zone between three major strike-slip faults (Ecemis, Kızılırmak, and Tuzgolu) (Piper et al., 2002). Cenozoic volcanism is represented by major central volcanoes, such as Erciyes, Hasan Dağ, and Melendiz Dağ; various volcanic rocks erupted from many monogenic centers. Cenozoic volcanic activity can largely be divided into three episodes as follows: a) basaltic andesitic volcanism (13.5-8.5 Ma), b) a rhyolitic and rhyodacite

*Corresponding author (e-mail: hosgorme@istanbul.edu.tr)

Copyright () 2015 by The Geochemical Society of Japan. ignimbrite eruption (11-2.8 Ma), and c) the formation of stratovolcanoes, such as Erciyes, Melendiz Dağ, and Hasan Dağ, as well as numerous small monogenetic centers that erupted during the late Pliocene until recent times (Piper et al., 2002).

The $\mathrm{CO}_{2}$ produced from different geological units and reservoirs exhibits different chemical characteristics. Previously published water chemistry data are presented in Table 1. The Karbogaz Field (Aksaray) is located in the eastern corner of the Tuz Gölü Basin. Two superimposed aquifers are located within the field: the lower confined (gypsum, siltstone, and sandstone) and the upper unconfined (alluvium). The lower confined aquifer contains a high amount of dissolved $\mathrm{CO}_{2}(20-30 \mathrm{mg} / \mathrm{L})$ (Geosan, 1998). According to their chemical composition, the wellhead waters are defined as $\mathrm{Na}-\mathrm{Ca}-\mathrm{HCO}_{3}-\mathrm{Cl}$-type waters (Table 1). The wellhead waters within the Bozkar Field are defined as $\mathrm{Na}-\mathrm{Cl}$-type waters and the amount of dissolved $\mathrm{CO}_{2}$ is $469.45 \mathrm{mg} / \mathrm{L}$ (Table 1). The Guneygaz-Kemerhisar Field, located to the south of the city Nigde, consists of two aquifers: tuffites and alluvium. The Kemerhisar region wellhead waters have a similar chemical composition to the $\mathrm{Na}-\mathrm{Cl}$-type water. While shallow reservoir water contains only small amounts of dissolved $\mathrm{CO}_{2}(2-21 \mathrm{mg} / \mathrm{L})$, the water within the tuffite aquifer has a high concentration of $\mathrm{CO}_{2}(102.8-1,280.7$ $\mathrm{mg} / \mathrm{L}$ ) (Table 1) (Geosan, 1998). In the Karapınar Field (Konya Province), water samples indicate predominantly $\mathrm{Na}-\mathrm{Cl} / \mathrm{Ca}-\mathrm{Mg}-\mathrm{HCO}_{3}$-type waters. The amount of dissolved $\mathrm{CO}_{2}$ varies in the range from 395.11 to $1,041.24$ $\mathrm{mg} / \mathrm{L}$ (Table 1). 
(a)

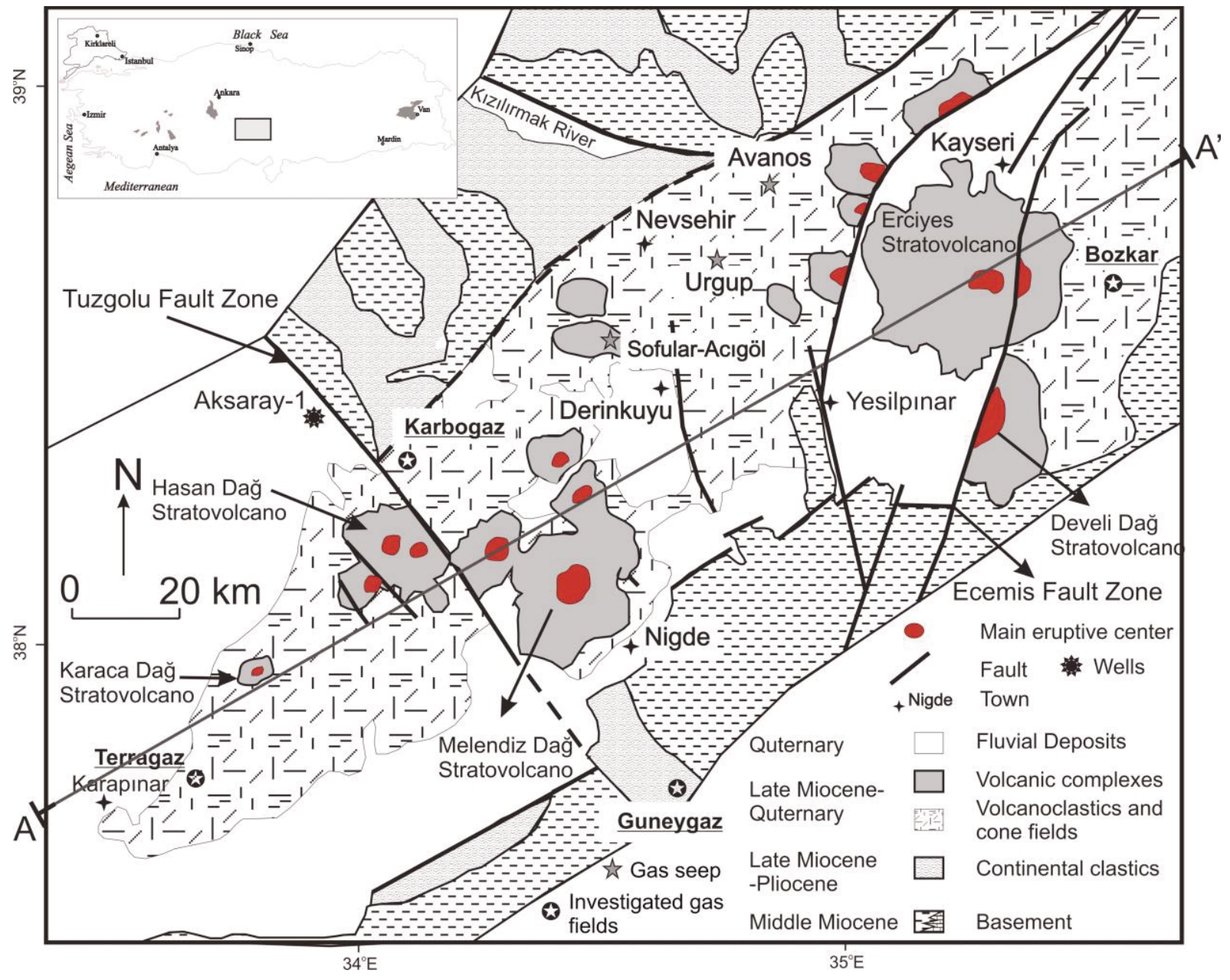

(b)

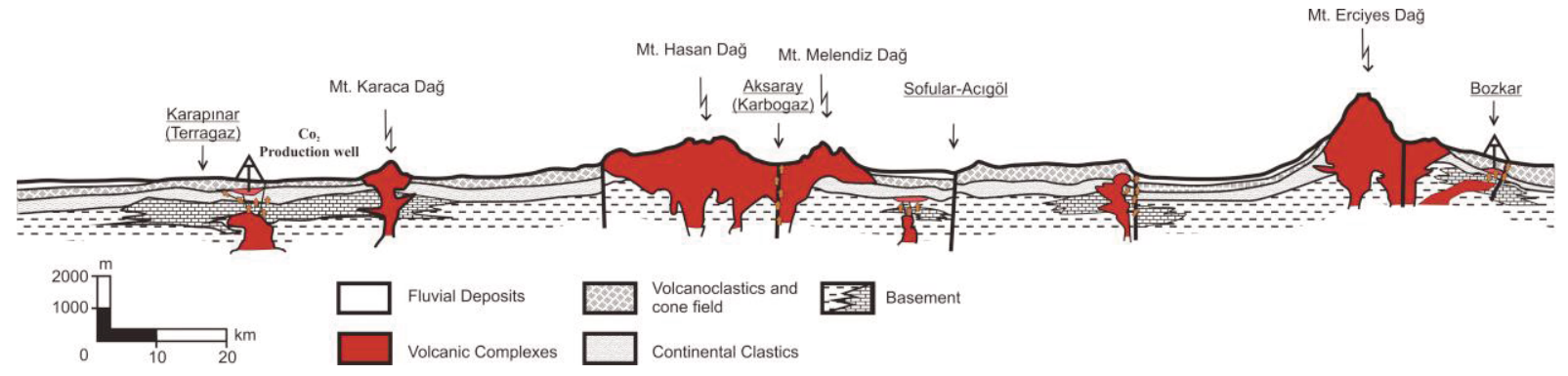

Fig. 1. (a) Location map of the study area, indicating the examined gas fields. The sample origin sites are indicated by stars. (b) A cross section $A-A^{\prime}$ across the gas fields Terragaz and Bozkar and major central volcanoes, such as Erciyes and Hasan Dă̆, prepared from a subsurface map. 
Table 1. The chemical composition and properties of water samples collected from Central Anatolia (as compiled by Camur and Mutlu (1996), Geosan (1998), and Mutlu and Güleç (1998))

\begin{tabular}{|c|c|c|c|c|c|c|c|c|c|c|c|}
\hline Location & Sample name & Determined water type & $\begin{array}{c}\mathrm{TDS} \\
\mathrm{mg} / \mathrm{l}\end{array}$ & $\begin{array}{c}\mathrm{Na} \\
\mathrm{mg} / \mathrm{l}\end{array}$ & $\begin{array}{c}\mathrm{K} \\
\mathrm{mg} / \mathrm{l}\end{array}$ & $\begin{array}{c}\mathrm{Ca} \\
\mathrm{mg} / \mathrm{l}\end{array}$ & $\begin{array}{l}\mathrm{Mg} \\
\mathrm{mg} / \mathrm{l}\end{array}$ & $\begin{array}{c}\mathrm{Cl} \\
\mathrm{mg} / \mathrm{l}\end{array}$ & $\begin{array}{c}\mathrm{HCO}_{3} \\
\mathrm{mg} / \mathrm{l}\end{array}$ & $\begin{array}{l}\mathrm{SO}_{4} \\
\mathrm{mg} / \mathrm{l}\end{array}$ & $\begin{array}{l}\mathrm{CO}_{2} \\
\mathrm{mg} / \mathrm{l}\end{array}$ \\
\hline Karbogaz (Aksaray) & $\mathrm{K} 1$ & $\mathrm{Na}-\mathrm{Ca}-\mathrm{HCO}_{3}-\mathrm{Cl}$ & 2307.9 & 312 & 35 & 264 & 63 & 446 & 1091.9 & 96 & 161.22 \\
\hline Bozkar (Kayseri) & B1 & $\mathrm{Na}-\mathrm{Cl}$ & 8991.8 & 2251 & 97 & 348 & 264 & 4205 & 1634.8 & 192 & 469.45 \\
\hline Guneygaz (Kemerhisar) & G1 & $\mathrm{Na}-\mathrm{Cl}$ & 16310.5 & 4646 & 343 & 250 & 380 & 8106 & 1433.5 & 1152 & 102.77 \\
\hline Guneygaz (Kemerhisar) & G2 & $\mathrm{Na}-\mathrm{Cl}-\mathrm{HCO}_{3}$ & 35313.1 & 10948 & 483 & 154 & 441 & 13685 & 7692.1 & 1910 & 1280.67 \\
\hline Terragaz (Karapınar) & $\mathrm{T} 1$ & $\mathrm{Na}-\mathrm{Ca}-\mathrm{Cl}-\mathrm{HCO}_{3}$ & 5102.6 & 690 & 66 & 460 & 170 & 1355 & 1805.6 & 556 & 395.11 \\
\hline
\end{tabular}

Table 2. He, $\mathrm{Ne}, \mathrm{Kr}, \mathrm{Xe}$, and $\mathrm{C}$ isotopic compositions and calculated $\mathrm{R} / \mathrm{R}_{\mathrm{A}}$ values for Central Anatolian gases (data taken from Ercan et al., 1995; Nagao et al., 1989)

\begin{tabular}{|c|c|c|c|c|c|c|c|c|c|c|c|}
\hline Locality & Latitude & Longitude & ${ }^{3} \mathrm{He} /{ }^{4} \mathrm{He}\left(\times 10^{-6}\right)^{\mathrm{a}}$ & $R / R_{\mathrm{A}}{ }^{\mathrm{b}}$ & Air-corrected $R / R_{\mathrm{A}}{ }^{\mathrm{c}}$ & ${ }^{4} \mathrm{He} /{ }^{20} \mathrm{Ne}$ & ${ }^{4} \mathrm{He}$ & ${ }^{20} \mathrm{Ne}$ & ${ }^{84} \mathrm{Kr}$ & ${ }^{132} \mathrm{Xe}$ & $\delta^{13} \mathrm{CO}_{2}$ \\
\hline Avanos & $38^{\circ} 43^{\prime}$ & $34^{\circ} 51^{\prime}$ & $1.73 \pm 0.12$ & 1.24 & 1.34 & 0.8 & 1 & 0.41 & 1.8 & 22 & 0.8 \\
\hline Ürgüp & $38^{\circ} 38^{\prime}$ & $34^{\circ} 55^{\prime}$ & $3.10 \pm 0.12$ & 2.23 & 2.25 & 18 & 19 & 0.33 & 1.8 & 2.1 & 0.7 \\
\hline Ziga (Aksaray) & $38^{\circ} 16^{\prime}$ & $34^{\circ} 17^{\prime}$ & $2.03 \pm 0.05$ & 1.46 & 1.59 & 1.1 & 1.9 & 0.55 & 1.7 & 1.7 & 0.7 \\
\hline Ziga (Aksaray) & $38^{\circ} 16^{\prime}$ & $34^{\circ} 17^{\prime}$ & $2.05 \pm 0.14$ & 1.47 & 1.58 & 1.3 & 2.1 & 0.51 & 1.7 & 2.2 & 0.5 \\
\hline Karapınar (Terragaz) & $37^{\circ} 46^{\prime}$ & $33^{\circ} 43^{\prime}$ & $1.59 \pm 0.06$ & 1.14 & 1.14 & 23 & 27 & 0.37 & 2 & 2.3 & -1.5 \\
\hline Kemerhisar (Guneygaz) & $38^{\circ} 48^{\prime}$ & $34^{\circ} 36^{\prime}$ & $2.54 \pm 0.05$ & 1.83 & 1.83 & 170 & 220 & 0.4 & 1.7 & 1.9 & 1.6 \\
\hline
\end{tabular}

${ }^{a}{ }^{4} \mathrm{He} /{ }^{20} \mathrm{Ne}$ ratios and He concentrations are those corresponding to minimum and maximum ${ }^{3} \mathrm{He} /{ }^{4} \mathrm{He}$ ratios.

${ }^{b} R / R_{A}$ values were directly quoted from the original reference, where available, or were calculated by normalizing the ${ }^{3} \mathrm{He} /{ }^{4} \mathrm{He}$ ratios given in the original reference to the atmospheric-He value $\left(1.39 \times 10^{-6}\right)$. The ratios from Pfister et al. (1997) were obtained by extrapolation from the $R / R_{A}$ vs. $\delta^{13}$ C plot presented in Güleç et al. (2002).

${ }^{c}$ Air-corrected $R / R_{A}$ ratios were obtained from those in column 6 , based on the assumption that all the neon in the samples is of atmospheric origin (the ${ }^{4} \mathrm{He} /{ }^{20} \mathrm{Ne}$ ratio of air-saturated water is considered as 0.24$)$. The $R / R_{A}$ ratios from Pfister et al. (1997) were assumed to be aircorrected ratios (Güleç et al., 2002).

The gas production in various wells in the Central Anatolian gas fields mainly consists of $\mathrm{CO}_{2}$ and a negligible amount of hydrocarbon gases. The hydrocarbon and $\mathrm{CO}_{2}$ gases within the gas fields are likely to have different formation mechanisms and origins. Ercan et al. (1995) collected six noble gases from Central Anatolia ( $\mathrm{He}, \mathrm{Ne})$, which were measured with a noble gas spectrometer (Table 2). Abundances and isotopic ratios were measured with the Finnigan Mat-250 instrument at the laboratory of Kobe, The University of Tokyo. Ercan et al. (1995) suggested that Central Anatolian He gases are derived from the mantle. Using ${ }^{3} \mathrm{He} /{ }^{4} \mathrm{He}$ and ${ }^{4} \mathrm{He} /{ }^{20} \mathrm{Ne}$ (neon) ratios and assuming that the samples were safely collected, the gases were evaluated to have a mixture of air, crustal, and mantle source. Although noble gases, such as $\mathrm{He}$ and $\mathrm{Ne}$, were studied in detail, $\mathrm{CO}_{2}$, the major constituent of gas fields, was only addressed for its origin with a very general approach. Additionally, Güleç et al. (2002) also discussed the origin of $\mathrm{He}$ gases and found evidence that mantlederived $\mathrm{He}$ is a plausible explanation. The maximum proportion of mantle-derived helium varies between 15 and $30 \%$ within the Central Anatolian volcanic province.

In a recent study, Mutlu et al. (2008) identified that the proportion of mantle-derived helium varies between 5 and 20\% within Western Anatolia.
To contribute to a realistic evaluation of the carbon dioxide potential of Central Anatolia, we sought to determine the origin of gases and to define their possible generation mechanisms. Therefore, as a first attempt, the molecular and isotopic compositions of the gases were investigated and the data were interpreted in terms of geological background.

We also discuss the origin of helium, based on data compiled from previously published papers (Ercan et al., 1995; Nagao et al., 1989; Güleç et al., 2002) (Table 2).

\section{METHODS}

Fourteen gas samples were taken from several gas fields (Fig. 1a) from different depth intervals using gas cylinders. Generally, the reservoir to be found water and $\mathrm{CO}_{2}$ mixing with pressure and springs out from wellhead. The gases were extracted from the separator and stored in a tank and samples from the tank were transferred into gas-tight cylinders. With the exception of Karapınar mineral water, which is produced from a well, the location had a free gas phase that was sampled for gas analysis (Fig. 2). Karapınar samples were extracted from the headspace of the glass bottles using a syringe and directly injected into a Gas Chromatograph Isotope Ratios mass 
spectrometer (GC-IRMS).

The sample measurements were performed by an Agilent-6890N gas chromatograph (GC) equipped with an flame ionization detector (FID) and thermal conductivity detector (TCD) to determine the type of hydrocarbons, their molecular composition, and the amount of $\mathrm{CO}_{2}$ gas in the samples. The gases were separated on the TCD detector by means of a GC equipped with an HP-Plot/Q (30 m; $0.542 \mathrm{~mm} ; 40.00 \mu \mathrm{m})$ and an HP-molsieve ( $30 \mathrm{~m}$; $0.539 \mathrm{~mm} ; 50.00 \mu \mathrm{m}$ ) column. Helium was used as the carrier gas. The hydrocarbon gases were deeply devised by an FID detector with an HP-AL/S (50 m; $0.534 \mathrm{~mm}$; $15.00 \mu \mathrm{m}$ ) column. The measurement results were evaluated by GC Chemstation software.

For the determination of the molecular composition of the gases, a correction was applied in order to eliminate admixtures of air. The air correction was calculated from the equation

$$
\mathrm{N}_{2 \text { corrected }}=\mathrm{N}_{2 \text { measured }}-\left(\mathrm{O}_{2 \text { measured }} \times 3.7\right) .
$$

Stable isotope analyses of the gases were performed using a GV-IsoPrism High Performance instrument with a continuous-flow GC-IRMS at the Turkish Petroleum Company (TPAO). The analytical precision was $\pm 0.3 \%$ o for methane and carbon dioxide and $\pm 0.5 \%$ for higher components $\left(>\mathrm{C}_{2}\right)$. The isotopic results are reported in $\delta \mathrm{D}$ and $\delta^{13} \mathrm{C}$ notation in parts per mil (\%o), relative to the Peedee Belemnite (PDB) standard for carbon and the Standard Mean Ocean Water (SMOW) for hydrogen, as

$$
\delta_{\text {sample }}=\left[\frac{R_{\text {sample }}}{R_{\text {standard }}}-1\right] \times 1000(\% \circ)
$$

where $R$ denotes the ratios $\mathrm{C}^{13} / \mathrm{C}^{12}$ or $\mathrm{D} / \mathrm{H}$, respectively.

\section{RESULTS}

The molecular and isotopic composition of gases

Fourteen gas samples from the four gas fields, Bozkar (Kayseri), Karbogaz (Aksaray), Terragaz (Karapınar), and Guneygaz (Kemerhisar-Niğde) (Fig. 1a), were analyzed for their molecular and isotopic composition. The concentrations of hydrocarbon gases, $\mathrm{C}_{1}, \mathrm{C}_{2+}$, nonhydrocarbon gases, and carbon dioxide $\left(\mathrm{CO}_{2}\right)$ were determined. As indicated by carbon dioxide concentrations from 80.7 to $94.3 \%$, the gas samples were rich in carbon dioxide $(>80 \%)$. The total amount of $\mathrm{CH}_{4+}$ components was less than $0.1 \%$ (Table 3 ).

The $\delta^{13} \mathrm{C}$ values of carbon dioxide in the Terragaz and Bozkar Fields varied in the range from -1.48 to $-1.76 \%$ o and 0.89 to $1.02 \%$, respectively. The $\delta^{13} \mathrm{C}$ composition of $\mathrm{CO}_{2}$ in the Karbogaz and Güneygaz Fields varied from

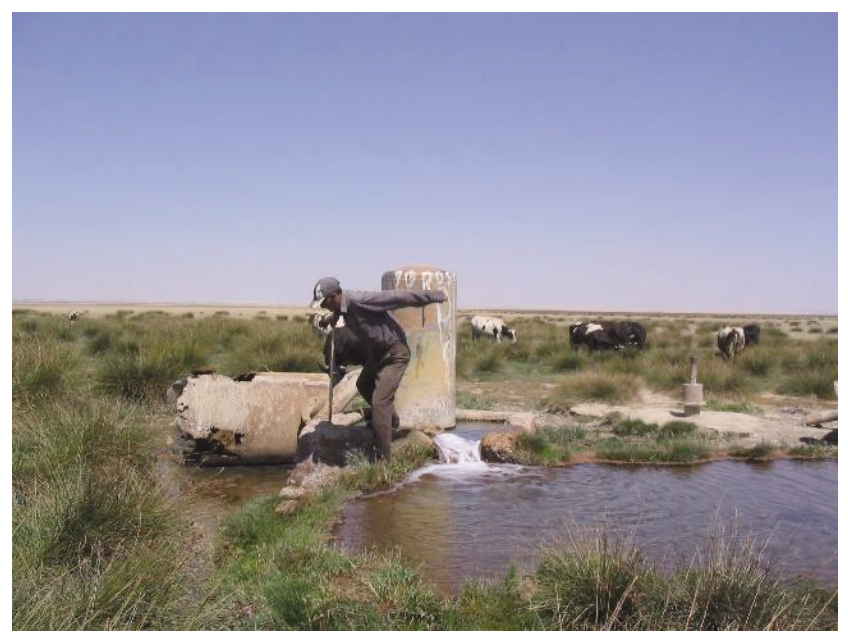

Fig. 2. Gas well and separator from Karapınar fields.

-0.03 to $-0.36 \%$ and 0.81 to $0.99 \%$, respectively. The $\delta^{13} \mathrm{C}$ value of methane from the Karbogaz Field ranged between -23.9 and $-24.2 \%$ (Table 3 ).

\section{The origin of gases}

To determine the origin of the hydrocarbon and carbon dioxide gases, different formation mechanisms were considered, which are separately discussed below.

The origin of methane Since the Karbogaz Field was the only site with a methane concentration within the detection limits of the GC-IRMS instrument, methane isotopic composition was only determined for this field. The origin of the hydrocarbon gases and possible processes for their generation were first investigated with the help of a Bernard diagram (Bernard et al., 1978), which uses the molecular composition, the $\mathrm{C}_{1} / \mathrm{C}_{2}+\mathrm{C}_{3}$ ratio, and $\delta^{13} \mathrm{C}$ values of methane. Data points for all the samples were plotted within the zone for thermal gas generation (Fig. 3a). Since both the isotopic and molecular composition of the gases can be impacted by migration or by the mechanism of gas generation (Whiticar, 1994; Hunt, 1996; Prinzhofer and Pernaton, 1997), another classification (according to Schoell, 1980) was applied using a genetic plot of the $\delta^{13} \mathrm{C}$ and $\delta \mathrm{D}$ of methane (Fig. 3b). As shown in Fig. 3b, gases from the Karbogaz Field were plotted within the thermal zone. An altered hydrocarbon isotopic composition was also observed for gaseous hydrocarbons generated from peat and lignite during high-pressure and hightemperature pyrolysis (Jiang et al., 2000). Suitable geological settings with high-pressure regimes that produce these types of gases are commonly found in basins near continental margins (Du et al., 2003). The methane isotopic composition indicated that the Karbogaz Field hydrocarbon gases are of thermogenic origin (Figs. 3a and b). 
(a)
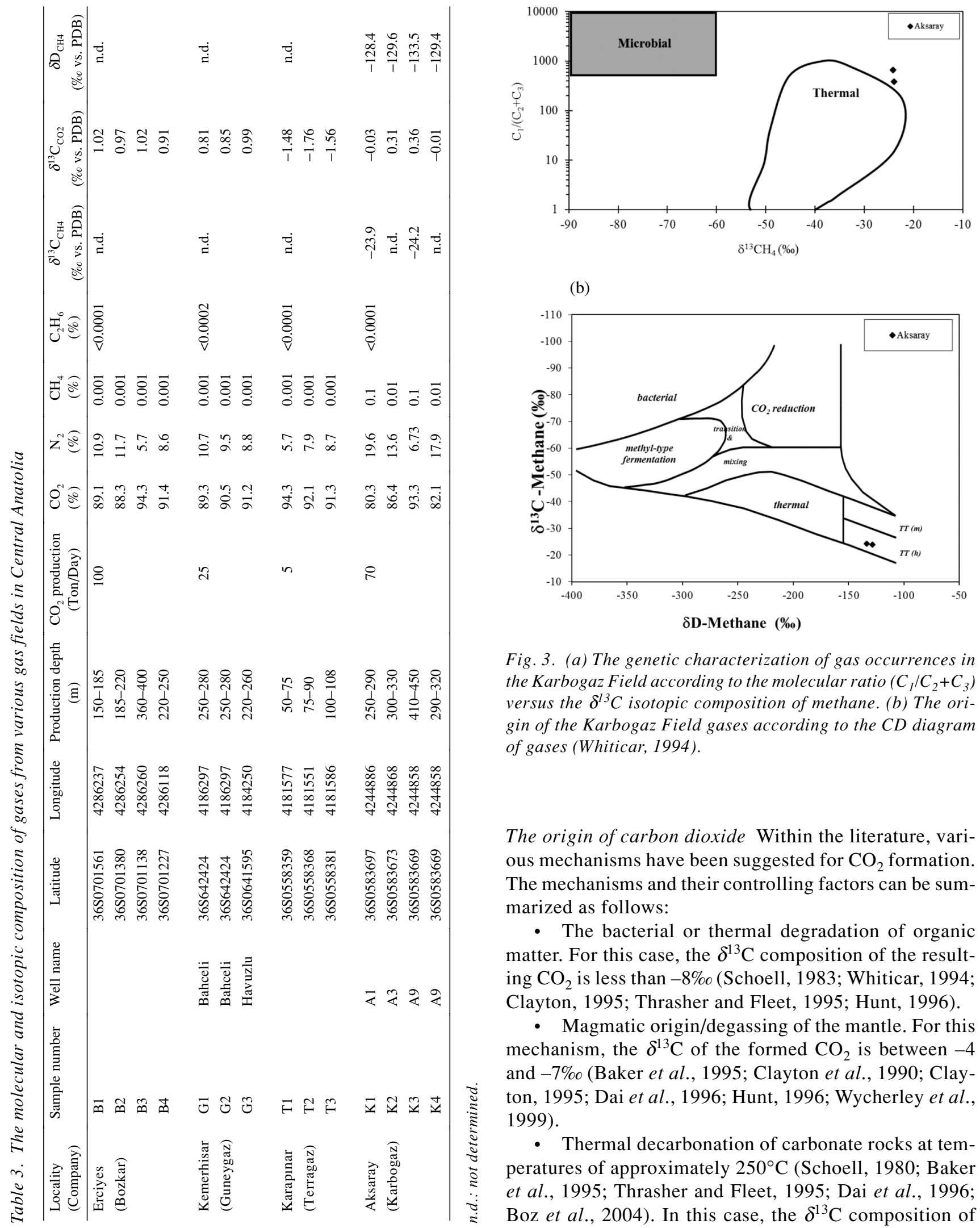

(b)

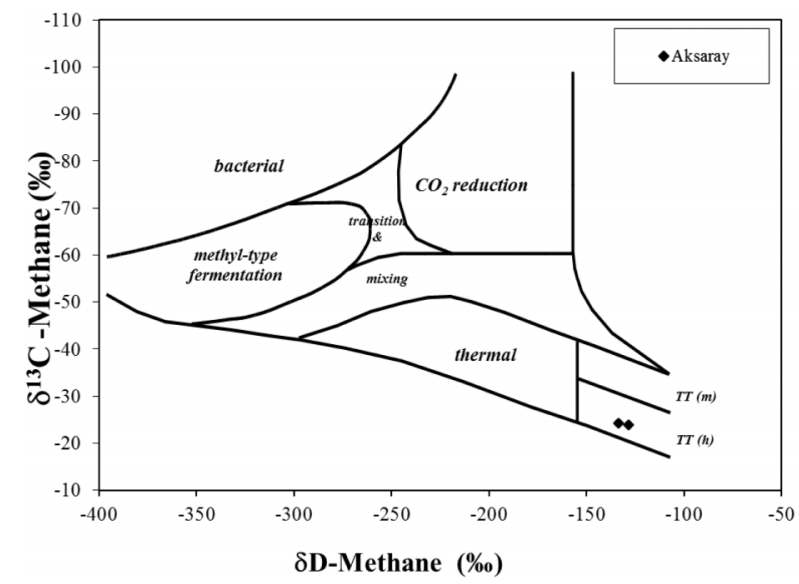

Fig. 3. (a) The genetic characterization of gas occurrences in the Karbogaz Field according to the molecular ratio $\left(C_{1} / C_{2}+C_{3}\right)$ versus the $\delta^{13} C$ isotopic composition of methane. (b) The origin of the Karbogaz Field gases according to the CD diagram of gases (Whiticar, 1994).

The origin of carbon dioxide Within the literature, various mechanisms have been suggested for $\mathrm{CO}_{2}$ formation. The mechanisms and their controlling factors can be summarized as follows:

- The bacterial or thermal degradation of organic matter. For this case, the $\delta^{13} \mathrm{C}$ composition of the resulting $\mathrm{CO}_{2}$ is less than -8\%o (Schoell, 1983; Whiticar, 1994; Clayton, 1995; Thrasher and Fleet, 1995; Hunt, 1996).

- Magmatic origin/degassing of the mantle. For this mechanism, the $\delta^{13} \mathrm{C}$ of the formed $\mathrm{CO}_{2}$ is between -4 and -7\%o (Baker et al., 1995; Clayton et al., 1990; Clayton, 1995; Dai et al., 1996; Hunt, 1996; Wycherley et al., 1999).

- Thermal decarbonation of carbonate rocks at temperatures of approximately $250^{\circ} \mathrm{C}$ (Schoell, 1980; Baker et al., 1995; Thrasher and Fleet, 1995; Dai et al., 1996; Boz et al., 2004). In this case, the $\delta^{13} \mathrm{C}$ composition of carbon dioxide is between 1 and $-3 \%$ (Shangguan and 


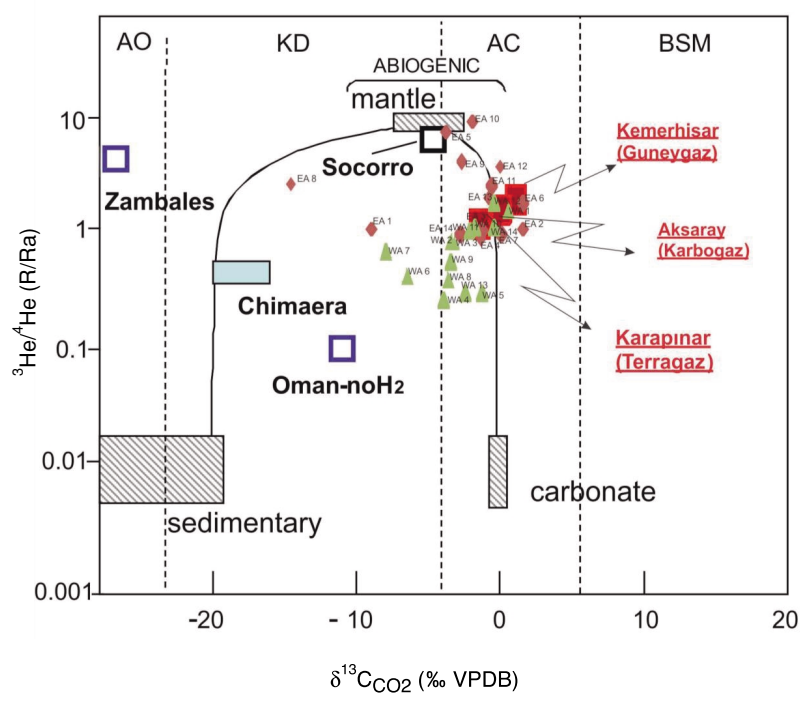

Fig. 4. He isotopic ratios vs. $\delta^{13} C_{\mathrm{CO}_{2}}$, assuming that the course of $\mathrm{CO}_{2}$ is a mixture of mantle-derived $\mathrm{CO}_{2}$ and $\mathrm{CO}_{2}$ produced either from organic or inorganic sedimentary material (the mixing curves are based on end-member values from Sano and Marty, 1995). Carbon dioxide isotopic zonation according to Jenden et al. (1993) and Hosgormez et al. (2008). AO: aerobic hydrocarbon oxidation; KD: kerogen decarboxylation; $A C$ : alteration of marine carbonates; BSM: biodegradation and secondary methanogenesis. The He isotopic ratio data are from Guleç et al. (2002). Western Anatolia data taken from Mutlu et al. (2008); WA1 Tuzla (spring), WA2 Kestanbol-1 (well), WA3 Kestanbol-2 (spring), WA4 Çan (well), WA5 Gönen (well), WA6 Manyas (well), WA7 Hisaralan (spring), WA8 Seferihisar (spring), WA9 Balçova (well), WA10 Germencik (spring), WA11 Germencik2 (spring), WA12 Kizlldere (well), WA13 Gazlıgöl (well), WA14 Ömer (well). Eastern Anatolia data from Mutlu et al. (2012); EA1 Ayrancı-Çaldıran, EA2 Buğulu-Çaldıran, EA3 Çamlık-Başkale, EA4 Çaybăgl-Saray, EA5 ÇukurGüroymak, EA6 Diyadin, EA7 Diyadin2, EA8 Germav-Hizan, EA9 Kokarsu-Bitlis, EA10 Nemrut caldera, EA11 Patnos-A ̆grt, EA12 Taşkapı-Erciş, EA13 Tutak-Van, EA14 Yurtbaşı-Gürpınar.

\section{Zhang, 1990).}

The variation of the isotopic composition of the Central Anatolian $\mathrm{CO}_{2}$ gases between -1.76 and $0.99 \%$ indicates that these gases were not formed as a result of the bacterial or thermal degradation of organic matter. Furthermore, the $\mathrm{CO}_{2}$ content in the gas fields is higher than $80 \%$. The amount of $\mathrm{CO}_{2}$ of organic origin is generally much lower (Tissot and Welte, 1984; Wycherley et al., 1999). While hydrocarbon gases are generated by the thermal degradation of organic matter, some organic $\mathrm{CO}_{2}$ can also be formed. However, the amount is much smaller than the $\mathrm{CO}_{2}$ formed by other mechanisms, such that no significant deviation is encountered in the isotopic composition. If the quantity of organic $\mathrm{CO}_{2}$ is equivalent or nearly equivalent to the amount of $\mathrm{CO}_{2}$ formed by an-

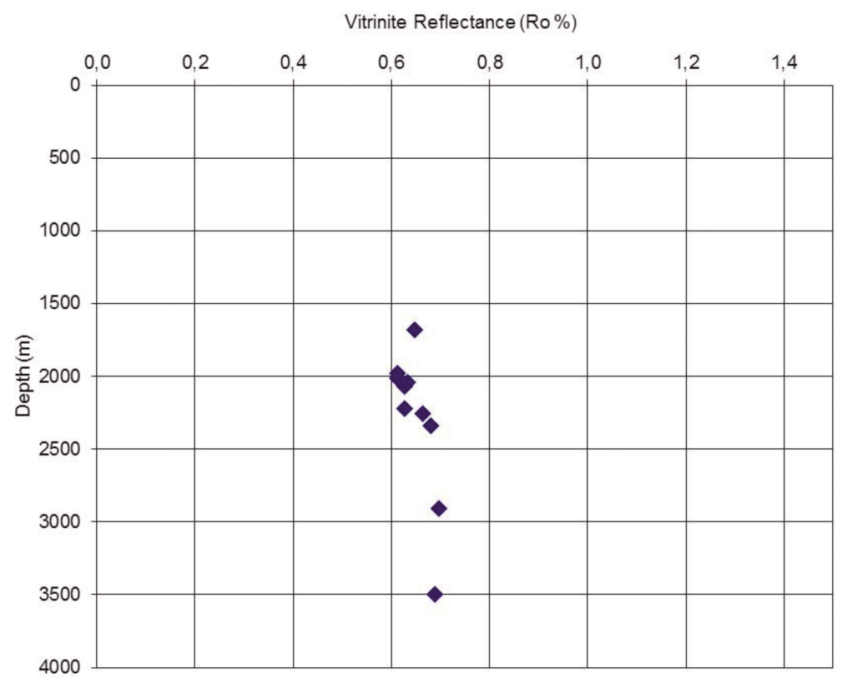

Fig. 5. The maturity (vitrinite reflectance) trend versus depth for the borehole Aksaray-1.

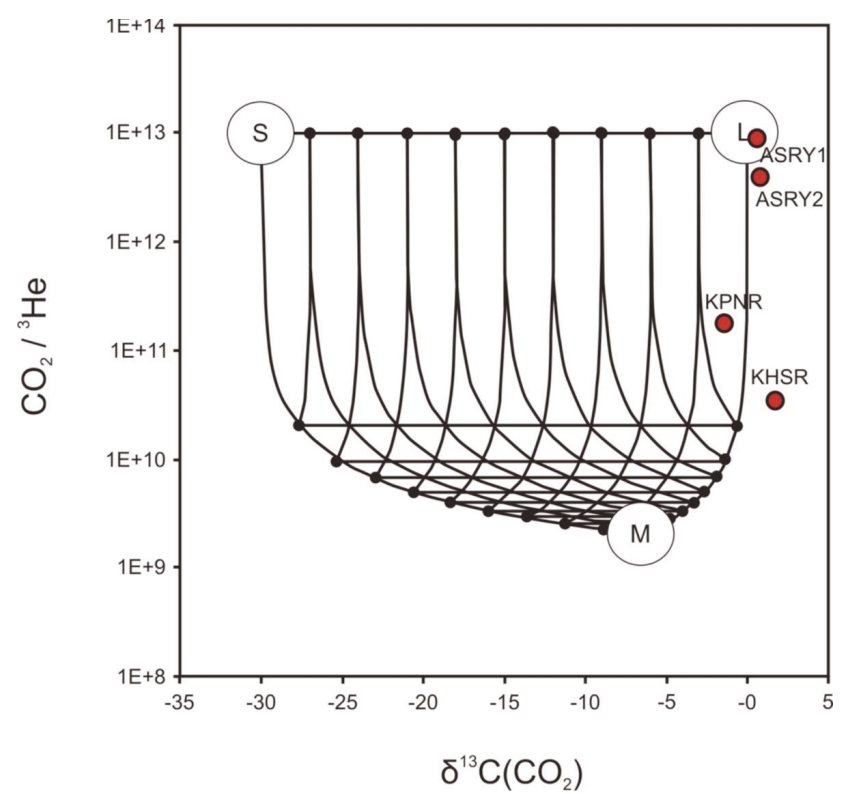

Fig. 6. Plot of $\mathrm{CO}_{2} /{ }^{3} \mathrm{He}$ vs. $\delta^{13} \mathrm{C}\left(\mathrm{CO}_{2}\right)$ for the Central Anatolian gas samples. The end-member compositions for sedimentary organic carbon $(S)$, mantle carbon $(M)$, and limestones $(L)$ are $\delta^{13} \mathrm{C}\left(\mathrm{CO}_{2}\right)=-30,-6.5$, and $0 \%$ and $\mathrm{CO}_{2} /{ }^{3} \mathrm{He}=1 \times 10^{13}, 2 \times$ $10^{9}$, and $1 \times 10^{13}$, respectively (Sano and Marty, 1995). ASRY: Aksaray; KPNR: Karapınar; KHSR: Kemerhisar sample (modified from Mutlu et al., 2008).

other mechanism, the $\mathrm{CO}_{2}$ isotopic composition should be close to that of the $\mathrm{CO}_{2}$ of organic origin $\left(\delta^{13} \mathrm{C}<\right.$ -8\%o) (Schoell, 1983; Whiticar, 1994; Clayton, 1995; Thrasher and Fleet, 1995; Hunt, 1996). The $\mathrm{CO}_{2}$ isotopic values of the Central Anatolian gas fields suggest that 
either the gases were not formed as a result of the bacterial or thermal degradation of organic matter or that the contribution by organic-origin $\mathrm{CO}_{2}$ is so small that it did not cause an isotopic deviation.

During the Middle Miocene-Holocene, several phases of volcanic activity occurred in Central Anatolia; namely, basaltic-andesitic volcanism during the mid-late Miocene, a rhyolitic and rhyodasitic ignimbrite eruption and the formation of stratovolcanoes, such as Erciyes, Melendiz Dağ, and Hasan Dağ, and the activity from several small monogenetic volcanic centers that have erupted from the late Pliocene to the present (Piper et al., 2002). As a result, the $\mathrm{CO}_{2}$ in the Central Anatolian gas fields is expected to be of mantle-derived magmatic origin and it may have been formed as a result of volcanic activity. In general, $\delta^{13} \mathrm{C}$ values close to $0 \%$ do not typically represent magmatic $\mathrm{CO}_{2}$, which is usually lighter ( -4 to $-8 \%$ ) (Macpherson and Mattey, 1994). However, the isotopic composition of $\mathrm{CO}_{2}$ within the study area ranged between -1.76 and $1.02 \%$, which differed from the mantle-derived magmatic-origin $\mathrm{CO}_{2}$ isotopic composition of $\delta^{13} \mathrm{C}$ by -4 to $-7 \%$ and was much heavier (Rigby and Smith, 1981; Koncz, 1983; Clayton et al., 1990; Baker et al., 1995; Thrasher and Fleet, 1995; Dai et al., 1996). On the other hand, the high $R / R$ a ratios in Fig. 4 indicate mantle-He contributions in regions of historically active volcanoes. Therefore, a minor amount of $\mathrm{CO}_{2}$ of magmatic origin cannot be excluded. Previous studies showed that large volumes of carbon dioxide (over $20 \mathrm{v} / \mathrm{v} \% \mathrm{CO}_{2}$ ) are a relatively uncommon occurrence in sedimentary basins. However, in regions where large volumes do occur, the stable carbon isotope ratio of $\mathrm{CO}_{2}$ is generally in the range of $\delta^{13} \mathrm{C}_{\mathrm{CO} 2} 0$ to $-10 \%$ PDB (Wycherley et al., 1999). These isotopic values are considered to indicate an inorganic origin, principally from either magmagenesis or contact metamorphism of carbonates.

Carbon dioxide with $\delta^{13} \mathrm{C}_{\mathrm{CO} 2}$ values in the range of -4 to $-7 \%$ and particularly large accumulations of carbon dioxide (i.e., $>15 \mathrm{v} / \mathrm{v} \%$ ) are considered to represent an inorganic origin, such as the decarbonation of carbonates. High temperatures are required for the thermal decarbonation of carbonate rocks (Boz et al., 2004). At temperatures higher than $250^{\circ} \mathrm{C}$, calcite is found to undergo thermal decarbonation and to form $\mathrm{CO}_{2}$ (Boz et al., 2004).

The following reactions indicate how $\mathrm{CO}_{2}$ can be formed in the presence of high temperatures as a result of the thermal decarbonation of limestone:

$$
\begin{aligned}
& \mathrm{CaCO}_{3}(\mathrm{~s}) \leftarrow \rightarrow \mathrm{Ca}_{2+}(\mathrm{aq})+\mathrm{CO}_{3}^{-2}(\mathrm{aq}) \\
& \mathrm{CO}_{3}^{-2}(\mathrm{aq})+\mathrm{H}_{2} \mathrm{O} \leftarrow \rightarrow 2 \mathrm{H}_{2} \mathrm{CO}_{3}(\mathrm{~g}) \\
& \mathrm{H}_{2} \mathrm{CO}_{3}(\mathrm{aq}) \leftarrow \rightarrow \mathrm{CO}_{2}(\mathrm{aq})+\mathrm{H}_{2} \mathrm{O}(\mathrm{l}) .
\end{aligned}
$$

In our study area, some carbonate rock has been reported within the Miocene-aged basement of the volcanic rocks covering large areas in the surface.

To determine whether the limestone sequence in the region underwent the necessary high temperatures required for thermal decarbonation, we examined the organic maturity trends in deep wells. Vitrinite reflectance values of organic matter from the Aksaray-1 well (near the study area) drilled by TPAO ranged between 0.5 and 0.7 (\%Ro) (Fig. 5). The data indicated an early maturation stage for organic matter and that the sequence did not experience high thermal overtime stress. Therefore, the temperatures required for carbonate decarbonation were definitely not reached at these depths. On the other hand, when the volcanic history of the basin was taken into consideration, the data indicated that portions of the sequence could have been affected by the higher temperatures caused by volcanic activity. Volcanic fluids and volcanic melt rising along main fault lines may have led to a local rise in temperature. Therefore, in volcanically active regions where igneous intrusive rocks intersect limestone, $\mathrm{CO}_{2}$ can be formed from the thermal decarbonation of limestone due to high temperatures $\left(>250^{\circ} \mathrm{C}\right)$.

The isotopic values of the $\mathrm{CO}_{2}$ formed by thermal decarbonation are similar to those of limestone (Shangguan and Zhang, 1990). Therefore, the isotopic composition of carbon dioxide within the study area $(-1.76$ to $1.02 \%$ o $)$ indicates that these gases can originate from limestone. A similar origin for carbon dioxide in other regions has also been proposed by various authors (Botz et al., 1996; Fiebig et al., 2004; D'Alessandro et al., 2008; Tassi et al., 2013). Carbon dioxide with isotopic values $\delta^{13} \mathrm{C}$ ranging from -2 to $2 \%,-1$ to $2 \%$, and -5 to $+4 \%$ o has been reported by Javoy et al. (1986), Hunt (1996), and Minissale et al. (1997), respectively. Since the isotopic composition of $\mathrm{CO}_{2}$ can be affected by mixing from other sources, a classification that uses genetic plots of $\delta^{13} \mathrm{C}$ and the He isotopic ratios of gases, according to Jenden et al. (1993) and Hosgormez et al. (2008), was also applied. In Fig. 4, gas data from central Anatolia are plotted within the mixing zone between carbonate and mantle origins. A shift in the respective values of high $R /$ $R$ a ratios is obvious and suggests mixing of carbonateorigin $\mathrm{CO}_{2}$ with mantle-origin $\mathrm{CO}_{2}$. Based on the magnitude of the shift in the $\delta^{13} \mathrm{C}$ values for $\mathrm{CO}_{2}$, it can be inferred that the amount of mantle-origin $\mathrm{CO}_{2}$ is low in the Central Anatolian gas fields (Fig. 4). This suggests that at least a high proportion of the $\mathrm{CO}_{2}$ emissions is derived from the breakdown of basement carbonates, either from heating by or direct reaction with magma (Fig. $1 b)$.

In order to examine in detail the deep magmatic and near-surface physical degassing processes in Central 
Anatolia, we have calculated the $\mathrm{CO}_{2} /{ }^{3} \mathrm{He}$ ratio of the gases. The three-component mixing model, reported by Sano and Marty (1995), was used to calculate the relative quantities of carbon sources contributing to arc magmas. As shown in Fig. 6, MORB (M), marine limestones (L), and organic sediments (S) were used to estimate the fraction of each $\mathrm{C}$ source for the gas samples.

A quantitative assessment of the various contributions to the carbon inventory is determined as an; the $\mathrm{L}$ source contributes $>90 \%$, the S source $<5 \%$, and the M source $<5 \%$. It is clear that carbon derived from marine limestone is the principal contributor to the carbon budget in all cases ( $>90 \%$ of the total). These values are in the same order as reported by Mutlu et al., 2008 and 2012 (Fig. 4).

\section{CONCLuSion}

The present study sought to determine the origin and formation mechanisms of gases in Central Anatolia and led to the following results:

1. As indicated by both the molecular and isotopic compositions, hydrocarbon gases in the Karbogaz Field are thermogenic. Relatively heavy isotopic values of methane suggest possible secondary effects, such as generation from high-pressure and high-temperature pyrolysis of peat and lignite.

2. Carbon isotopic data indicate that $\mathrm{CO}_{2}$ is mainly formed from the decarbonation of limestone. Furthermore, helium isotopic values suggest that minor amounts of $\mathrm{CO}_{2}$ are derived from the mantle. Therefore, the $\mathrm{CO}_{2}$ gas in Central Anatolia is produced from multiple sources.

3. A dominant limestone component has been established for the $\mathrm{CO}_{2}$ source with contributions from each of the sedimentary and mantle components not exceeding about $10 \%$ of the total inventory. It is apparent that limestone is the major contributor to the carbon inventory of all samples $(>90 \%)$, followed by sedimentary organic and mantle sources.

4. According to the thermal history of the basin, well data on temperature, and the maturity of organic matter, it can hardly be concluded that the temperatures $\left(>250^{\circ} \mathrm{C}\right)$ required for decarbonation were regionally reached. However, such temperatures could be reached locally at the contact zones of limestone with uprising volcanic bodies.

5. The $\mathrm{CO}_{2}$ formed at the contact metamorphism zones of limestone migrated along fracture zones, dissolved in water upward, until its movement was stopped by impermeable beds, such as evaporites. Hence, the present $\mathrm{CO}_{2}$ occurrences are located just below these impermeable beds.

Acknowledgments-The author is grateful for the financial support by the TUBITAK (The Scientific and Technical Re- search Council of Turkey; Project No: 107Y205) and University of Istanbul Research Fund (Project number ONAP-24702, 22337). Prof. Dr. M. Namık YALÇIN, Istanbul University is thanked for valuable comments, which markedly improved the manuscript. We thank Dr. Masahiko HONDA for his insightful reviews and constructive criticism and comments, which greatly improved the manuscript. Appreciation is extended to Mark Kendrick for their critical comments that helped improved the manuscript.

\section{REFERENCES}

Baker, J. C., Bai, G. P., Hamilton, P. J., Golding, S. D. and Keene, J. B. (1995) Continental scale magmatic carbon dioxide seepage recorded by dawsonite in the BowenGunnedah-Sydney Basin system, Eastern Australia. J. Sediment. Res. A65, 522-530.

Bernard, B. B., Brooks, J. M. and Sackett, W. M. (1978) Light hydrocarbons in recent Texas continental shelf and slope sediments. J. Geophys. Res. 83, 4053-4061.

Botz, R., Stüben, D., Winckler, G., Bayer, R., Schmitt, M. and Eckhard, F. (1996) Hydrothermal gases offshore Milos Island, Greece. Chem. Geol. 130, 161-173.

Boz, I., Pozan, G. S. and Gürkaynak, M. A. (2004) Tetradecanol dehyrogenation over $\mathrm{CuO}$ catalyst supported on $\mathrm{BaO}, \mathrm{CaO}$ and $\mathrm{MgO}$. React. Kinet. Catal. Lett. 83, 137-146.

Camur, M. Z. and Mutlu, H. (1996) Major-ion geochemistry and mineralogy of the Salt Lake (Tuz Gölü) Basin, Turkey. Chem. Geol. 127, 313-329.

Clayton, C. J. (1995) Controls on the carbon isotopic ratio of carbon dioxide in oil and gas fields. 17th Proceedings International Meeting on Organic Geochemistry, 1073-1074.

Clayton, J. L., Spencer, C. W., Koncz, I. and Szalay, A. (1990) Origin and migration of hydrocarbon gases and carbon dioxide, Bekes Basin, Southern Hungary. Org. Geochem. 15, 233-247.

Dai, J. X., Song, Y., Dai, C. S. and Wang, D. R. (1996) Geochemistry and accumulation of carbon dioxide gases in China. AAPG 80, 1615-1626.

D’Alessandro, W., Brusca, L., Kyriakopoulos, K., Michas, G. and Papadakis, G. (2008) Methana, the western most active volcanic system of the south Aegean arc (Greece): Insight from fluids geochemistry. J. Volcanol. Geotherm. Res. 178, $818-828$.

Du, J., Jin, Z., Xie, H., Bai, L. and Liu, W. (2003) Stable carbon isotope compositions of gaseous hydrocarbons produced from high pressure and high temperature pyrolysis of lignite. Org. Geochem. 34, 97-104.

Ercan, T., Matsuda, J. I., Nagao, K. and Kita, I. (1995) Noble gas isotopic compositions in gas and water samples from Anatolia. Proc. Int. Symp. on the Geology of the Black Sea Region, 1st, 197-206.

Fiebig, J., Chiodini, G., Caliro, S., Rizzo, A., Spangenberg, J. and Hunziker, J. C. (2004) Chemical and isotopic equilibrium between $\mathrm{CO}_{2}$ and $\mathrm{CH}_{4}$ in fumarolic gas discharges: generation of $\mathrm{CH}_{4}$ in arc magmatic-hydrothermal systems. Geochim. Cosmochim. Acta 68, 2321-2334.

Geosan, A. Ş. (1998) Karbogaz A. Ş. Aksaray Aratol doğal karbondioksit üretimi olanakları (unpublished report). 
Gevrek, A. I. and Kazancı, N. (2000) A Pleistocene, pyroclasticpoor maar from Central Anatolia, Turkey: influence of a local fault on a phreatomagmatic eruption. J. Volcanol. Geotherm. 95, 309-317.

Güleç, N., Hilton, D. R. and Mutlu, H. (2002) Helium isotope variations in Turkey: relationship to tectonics, volcanism and recent seismic activities. Chem. Geol. 187, 129-142.

Hosgormez, H., Etiope, G. and Yalçın, M. N. (2008) New evidence for a mixed inorganic and organic origin of the Olympic Chimaera fire (Turkey): a large onshore seepage of abiogenic gas. Geofluids 8, 263-275.

Hunt, J. M. (1996) Petroleum Geochemistry and Geology. 2nd ed., W.H. Freeman Co., 743 pp.

Javoy, M., Pineau, F. and Delorme, H. (1986) Carbon and nitrogen isotopes in the mantle. Chem. Geol. 57, 41-62.

Jenden, P. D., Hilton, D. R., Kaplan, I. R. and Craig, H. (1993) Abiogenic hydrocarbons and mantle helium in oil and gas fields. Future of Energy Gases: USGS, Professional Paper (Howell, D., ed.), 31-35, United States Geological.

Jiang, F., Du, J., Xie, H. and Wang, W. (2000) Evolution characteristics of $\delta^{13} \mathrm{C}$ values of gaseous hydrocarbons under high-temperature and high-pressure conditions as suggested by aqueous pyrolysis. Geochemica 29, 73-76.

Koncz, I. (1983) The stable carbon isotope composition of the hydrocarbon and carbon dioxide components of Hungarian natural gases. Acta Mineralogica-Petrographica, Szeged, XXVI(1), 33-49.

Kuşcu, G. G., Atilla, C., Cas, R. A. and Kuşcu, I. (2007) Base surge deposits, eruption history, and depositional processes of a wet phreatomagmatic volcano in Central Anatolia (Cora Maar). J. Volcanol. 159, 198-209.

Macpherson, C. G. and Mattey, D. P. (1994) Carbon isotope variations of $\mathrm{CO}_{2}$ in Lau Basin basalts and ferrobasalts. Earth Planet. Sci. Lett. 121, 263-276.

Minissale, A., Evans, W., Magro, G. and Vaselli, O. (1997) Multiple source components in gas manifestations from north-central Italy. Chem. Geol. 142, 175-192.

Mutlu, H. and Güleç, N. (1998) Hydrogeochemical outline of thermal waters and geothermometry applications in Anatolia (Turkey). J. Volcanol. Geotherm. 85, 495-515.

Mutlu, H., Güleç, N. and Hilton, D. R. (2008) Helium-carbon relationships in geothermal fluids of western Anatolia, Turkey. Chem. Geol. 247, 305-321.

Mutlu, H., Güleç, N., Hilton, D. R., Aydın, H. and Halldorsson, S. A. (2012) Spatial variations in gas and stable isotope compositions of thermal fluids around Lake Van: Implications for crust-mantle dynamics in eastern Turkey. Chem. Geol. 300, 165-176.

Nagao, K., Matsuda, J. I., Kita, I. and Ercan, T. (1989) Noble gas and carbon isotopic compositions in Quaternary volcanic area in Turkey. Bull. Geomorphology 17, 101-110.

Pearce, J. A., Bender, J. F., De Long, S. E., Kidd, W. S. F., Low, P. J., Güner, Y., Şaroğlu, F., Yılmaz, Y., Moorbath, S. and
Mitchell, J. G. (1990) Genesis of collision volcanism in eastern Anatolia, Turkey. J. Volcanol. Geotherm. 44, 189229.

Pfister, M., Balderer, W., Greber, E., Kahle, H. G., Mayer-Rosa, D., Mueller, S., Rybach, L., Schindler, C., Sellami, S. and Straub, C. (1997) Synthesis of the Marmara poly-project. Active Tectonics of Northwestern Anatolia-the Marmara Poly-Project (Schindler, C. and Pfister, M., eds.), 539-565, Vdf Hochschulverlag an der ETH, Zurich.

Piper, J. D. A., Gürsoy, H. and Tatar, O. (2002) Palaeomagnetism and magnetic properties of the Cappadocian ignimbrite succession, central Turkey and Neogene tectonics of the Anatolian collage. J. Volcanol. Geotherm. 117, 237-262.

Prinzhofer, A. and Pernaton, E. (1997) Isotopically light methane in natural gas: Bacterial imprint or diffusive fractionation. Chem. Geol. 142, 193-200.

Rigby, D. and Smith, J. W. (1981) An isotopic study of gases and hydrocarbons in the Cooper Basin. Aust. Petrol. Explor. Assoc. J. 21, 222-229.

Sano, Y. and Marty, B. (1995) Origin of carbon in fumarolic gas from island arcs. Chem. Geol. 119, 265-274.

Schoell, M. (1980) The Hydrogen and carbon isotopic composition of methane from natural gases of various origins. Geochem. Cosmochem. Acta 44, 649-661.

Schoell, M. (1983) Genetic characterization of natural gases. $A A P G$ 67, 2225-2238.

Shangguan, Z. and Zhang, P. (1990) Active faults in Northwestern Yunnan Province. Seismology Press, 164 pp. (in Chinese).

Tassi, F., Vaselli, O., Papzachos, C. B., Giannini, L., Chiodini, G., Vougioukalakis, G. E., Karagianni, E., Vamvakaris, D. and Panagiotopoulos, D. (2013) Geochemical and isotopic changes in the fumarolic and submerged gas discharges during the 2011-2012 unrest at Santorini caldera (Greece). Bull. Volcanol. 75, 711.

Thrasher, J. and Fleet, A. J. (1995) Predicting the risk of carbon dioxide 'pollution' in petroleum reservoirs. 17th Proceedings International Meeting on Organic Geochemistry, 1086-1088.

Tissot, B. P. and Welte, D. H. (1984) Petroleum Formation and Occurrence. Springer, $224 \mathrm{pp}$.

Toprak, V. and Göncüoğlu, M. C. (1993) Tectonic control on the development of the Neogene-Quaternary Central Anatolian volcanic province, Turkey. Geol. J. 28, 357-369.

Whiticar, M. J. (1994) Correlation of natural gases with their sources. AAPG Memoir. 60, 261-283.

Wycherley, H., Fleet, A. and Shaw, H. (1999) Some observations on the origins of large volumes of carbon dioxide accumulations in sedimentary basins. Mar. Petrol. Geol. 16, 489-494.

Yılmaz, Y., Güner, Y. and Şaroğlu, F. (1998) Geology of the Quaternary volcanic centers of the east Anatolia.J. Volcanol. Geotherm. 85, 173-210. 